\section{Thermal Analysis of Dormant Buds of Two Muscadine Grape Cultivars and of Vitis labrusca L. 'Mars'}

\author{
John R. Clark ${ }^{1}$ \\ Department of Horticulture, 316 Plant Science, University of Arkansas, \\ Fayetteville, AR 72701
}

\author{
Tony K. Wolf ${ }^{1}$ and M. Kay Warren ${ }^{2}$ \\ Winchester Agricultural Research and Extension Center, Virginia Polytechnic \\ Institute and State University, 595 Laurel Grove Road, Winchester, VA 22602
}

Additional index words. differential thermal analysis, cold hardiness, Vitis rotundifolia

\begin{abstract}
Thermal analysis was used to determine if muscadine grape (Vitis rotundifolia Michx.) buds supercool and to determine the seasonal cold hardiness of several grape cultivars grown in Arkansas. Buds of the muscadine cultivars Carlos and Summit, sampled from vines grown at Clarksville, Ark., produced low-temperature exotherms consistent with the number of buds tested. Apparent hardiness of the buds increased from 5 Nov. 1993 through 7 Jan. 1994. Mean low-temperature exotherms (MLTE) were lowest on 7 Jan. and were-21.5C for 'Carlos' and -23.4C for 'Summit'. 'Mars' buds, sampled at Clarksville, Ark., and Winchester, Va., were included in the study and increased in hardiness during the same period. MLTE for 'Mars' from Arkansas were similar to those of the muscadine cultivars on 7 Jan.; however, 'Mars' attained lower MLTE temperatures with vines grown in Virginia than with those in Arkansas. Location differences in hardiness of 'Mars' are conjectural.
\end{abstract}

Thermal analysis (TA) and differential thermal analysis have been used to determine cold hardiness of dormant buds of several species of Vitis (Andrews et al., 1984; Bourne et al., 1991; Pierquet and Stushnoff, 1980; Pierquet et al., 1977; Quamme, 1986; Wolf and Cook, 1992, 1994). Those studies determined that dormant grape buds supercool and that the latent heat of fusion released when the supercooled tissue freezes can be detected by thermocouples or by thermoelectric modules. Studies of bud excision procedure and cooling rate indicated that buds should be excised with 1 to $2 \mathrm{~mm}$ of subjacent nodal tissue and cooled at $<10 \mathrm{C} / \mathrm{h}$ (Quamme, 1986; Wolf and Pool, 1987). TA has favorably predicted field survival of Vitis buds (Wolf and Cook, 1994) and has found utility in acclimation and deacclimation studies (Pool et al., 1992; Wolf and Cook, 1992), breeding programs (Bourne etal., 1991), and investigations of the impact of cultural practices on vine hardiness (Hamman et al., 1990; Wample, 1994; Wample et al., 1993).

Species of grape in the subgenus Muscadinia include the muscadine grape. This species is native to the southern United States

Received for publication 30 Mar. 1995. Accepted for publication 3 Nov. 1995. Arkansas Agricultural Experiment Station manuscript no. 95021. The cost of publishing this paper was defrayed in part by the payment of page charges. Under postal regulations, this paper therefore must be hereby marked advertisement solely to indicate this fact.

${ }^{1}$ Associate Professor.

${ }^{2}$ Agricultural Manager. and is usually not recommended to be planted in areas where winter minima drop below-12C; vine injury or death can occur at $-18 \mathrm{C}$ or below (Ahmedullah and Himelrick, 1990). Information on variation in hardiness of muscadine cultivars is limited, and what information exists has usually been generated by field evaluation. Hardy cultivars include 'Carlos', 'Sterling', 'Nesbitt', 'Magnolia', and 'Doreen' (Poling et al., 1989). We are not aware of any reports of TA being used with muscadine grapes.

Since TA has been successfully used to determine primary bud hardiness of Euvitis species, we were interested in determining if TA could be used with muscadine dormant buds. This study was undertaken to determine if muscadine grape buds supercool and if TA could be used to determine primary bud hardiness. In addition to the muscadine cultivars, 'Mars' was included to serve as a Euvitis control because it has been used in a TA research study and primary buds produce lowtemperature exotherms (LTE) (Bourne et al., 1991).

\section{Materials and Methods}

Plant material. Vines used in this study were grown at the Univ. of Arkansas Fruit Substation, Clarksville, and at Virginia Tech's Winchester Agricultural Research and Extension Center (AREC) in Winchester. 'Carlos' and 'Summit' muscadine vines, growing at the Arkansas location, were 11 years old and were trained to a bilateral cordon training system. Vines had been pruned to 3- to 4-node spurs each dormant season before the study but were not pruned before the collection of buds for this study. There were three single-vine replications of each cultivar arranged in a randomized complete-block design in the planting. Eight-year-old 'Mars' vines grown at Clarksville also were sampled. 'Mars' vines were trained to a four-arm Kniffin system and cane-pruned in all years before this study. There were four three-vine replications of 'Mars' planted in a randomized completeblock design. Vines at Clarksville were trickleirrigated, and weeds were controlled with preemergent herbicides. Fungal diseases were controlled with fungicides on 'Mars', but no fungicides were applied to the muscadine vines due to their natural resistance to the more common grape fungal pathogens. Single canes from the upper, sunlight-exposed portion of the vine canopy of each replication of each cultivar were collected at each sample date to include nodes 2 through 12. Canes from all vines sampled in Arkansas were collected on 3, 19, and 30 Nov. and 14 Dec. 1993 and 5 Jan. 1994. The canes were shipped via overnight mail in sealed plastic bags to Winchester, where samples were stored at 2C. Canes were shipped at ambient temperatures, and the conditions during shipment were not recorded. The canes usually arrived within $28 \mathrm{~h}$ of collection. TA was typically conducted within 48 $\mathrm{h}$ of sample collection from the field. An exception to this schedule occurred with the 19 Nov. sample, which was delayed 2 days in transit and was not evaluated until 24 Nov. 'Mars' canes also were collected the day of TA from 4-year-old vines grown at the Winchester AREC to provide an indication of any hardiness differences between the locations and to serve as a verification that the TA system was operating correctly, using either locally collected or shipped buds. 'Mars' at Winchester were trained to a U-shaped divided canopy trellis, using quadrilateral cordon training, spur pruning, and vertical shoot positioning.

Dormant bud TA. Buds from node positions 3 to 11 were used for TA. The buds were excised from the canes with 0.5 to $1.0 \mathrm{~mm}$ of subtending nodal tissue attached to the bud. Buds were mounted on thermoelectric modules (TM) (MELCOR, Trenton, N.J.) with a strip of water-moistened filter paper to promote ice nucleation of moisture at the budthermoelectric module interface (Wolf and Pool, 1987). For each test date, three to five buds of each cultivar were mounted on each of four or five modules. This method resulted in a total of 12 to 20 buds tested per cultivar at each date. Loaded modules were cooled from 0 to $-35 \mathrm{C}$ at 4 to $6 \mathrm{C} / \mathrm{h}$ in a programmable freezer. TMvoltage and separate thermocouple temperature data were recorded every $20 \mathrm{sec}$ with data acquisition hardware (Wolf and Pool, 1986) and then plotted to determine the LTE temperatures. LTE values for each cultivar at each date were averaged to determine mean LTE (MLTE). The temperature lethal to $10 \%$ $\left(\mathrm{LT}_{10}\right)$ and $90 \%\left(\mathrm{LT}_{90}\right)$ of a cultivar's buds also was determined by ranking the temperatures of all LTE events for that cultivar at each date. 
Table 1. Dormant bud hardiness estimates of 'Carlos' and 'Summit' muscadine (Arkansas) and 'Mars' bunch grapes at Clarksville, Ark., and Winchester, Va., during the 1993-94 dormant period.

\begin{tabular}{|c|c|c|c|c|c|c|c|c|c|c|c|c|}
\hline \multirow{5}{*}{$\begin{array}{l}\text { Date } \\
\text { tested }\end{array}$} & \multicolumn{12}{|c|}{ Temp criterion $\left({ }^{\circ} \mathrm{C}\right)$} \\
\hline & \multicolumn{12}{|c|}{ Cultivar } \\
\hline & & & & & & & \multicolumn{6}{|c|}{ Mars } \\
\hline & \multicolumn{3}{|c|}{ Carlos $^{2}$} & \multicolumn{3}{|c|}{ Summit } & \multicolumn{3}{|c|}{ Arkansas } & \multicolumn{3}{|c|}{ Virginia } \\
\hline & $\mathrm{LT}_{10}$ & MLTE & $\mathrm{LT}_{90}$ & $\mathrm{LT}_{10}$ & MLTE & $\mathrm{LT}_{90}$ & $\mathrm{LT}_{10}$ & MLTE & $\mathrm{LT}_{90}$ & $\mathrm{LT}_{10}$ & MLTE & $\mathrm{LT}_{90}$ \\
\hline 5 Nov. & -6.6 & $-11.1 \pm 1.08$ & -12.8 & -6.8 & $-11.5 \pm 1.39$ & -13.5 & -6.7 & $-11.6 \pm 1.20$ & -13.2 & -11.6 & $-13.0 \pm 0.57$ & -13.8 \\
\hline 24 Nov. & -7.8 & $-12.8 \pm 1.75$ & -17.1 & -9.5 & $-13.3 \pm 0.91$ & -14.6 & -10.3 & $-14.3 \pm 1.12$ & -15.7 & -14.6 & $-18.0 \pm 1.03$ & -19.4 \\
\hline 2 Dec. & -14.4 & $-18.0 \pm 1.11$ & -19.4 & -10.3 & $-18.5 \pm 1.70$ & -21.2 & -20.4 & $-21.9 \pm 0.62$ & -23.3 & -14.4 & $-19.2 \pm 1.30$ & -20.7 \\
\hline 16 Dec. & -15.1 & $-20.1 \pm 1.54$ & -22.4 & -15.2 & $-19.9 \pm 1.28$ & -22.4 & -18.0 & $-19.8 \pm 0.71$ & -21.1 & -23.5 & $-24.3 \pm 0.41$ & -25.3 \\
\hline 7 Jan. & -16.8 & $-21.5 \pm 1.41$ & -24.6 & -22.3 & $-23.4 \pm 0.56$ & -24.5 & -19.6 & $-22.4 \pm 0.98$ & -24.3 & -24.9 & $-26.5 \pm 0.54$ & -27.2 \\
\hline
\end{tabular}

${ }^{2} \mathrm{LT}_{10}, \mathrm{LT}_{90}=$ temperature lethal to $10 \%$ and $90 \%$ of the buds tested, respectively; MLTE $=$ mean low-temperature exotherm $\pm \mathrm{SE}$.

\section{Results and Discussion}

Buds of both muscadine cultivars produced LTE on all test dates, confirming that muscadine grape buds supercool. Muscadine buds typically produced a single, relatively large LTE and, inconsistently, one, or rarely two, much smaller exotherms (data not shown). That pattern is consistent with the compound nature of muscadine buds and was similar to the pattern observed with Euvitis buds (Wolf and Pool, 1987). As the fall progressed, the $\mathrm{LT}_{10}$, MLTE, and $\mathrm{LT}_{90}$ temperatures decreased (Table 1). Maximum bud hardiness, inferred from lowest MLTE values, was recorded on the last sample date (7 Jan. 1994). The two muscadine cultivars produced similar MLTE values during the sampling period, although the MLTE of 'Summit' was lower than that of 'Carlos' on 7 Jan. 'Summit' was rated less hardy than 'Carlos' in a field evaluation of hardiness following a-21.6C exposure (Clark and Moore, 1990). In our study, vines at Clarksville were exposed to a winter minimum of $-13 \mathrm{C}$ on 19 Jan. 1994, a temperature at which we would not have predicted injury to occur. Nevertheless, bud assays of 165 buds per cultivar on 10 Feb. 1994 indicated 29\% and $42 \%$ dead buds for 'Carlos' and 'Summit' vines, respectively. Due to the bud injury, further hardiness tests produced unreliable results and are not included in this report. The Arkansas 'Mars' attained an $\mathrm{LT}_{10}$ and a MLTE of $-19.6 \mathrm{C}$ and $-22.4 \mathrm{C}$, respectively, by 7 Jan. 1994 (Table 1). Again, these values would not have predicted significant bud injury of 'Mars' with a field exposure of $-13 \mathrm{C}$. 'Mars', however, had $9 \%$ primary bud kill in the viability assessment made on $10 \mathrm{Feb}$. The hardiness of Arkansas 'Mars', as well as the muscadine cultivars, appeared to have been overestimated by TA. The bud kill in excess of the predicted level could be due to the length of time the buds were exposed to $-13 \mathrm{C}$. However, the time of exposure was not recorded and cannot be confirmed. Another possibility to explain the bud kill is that damage occurred at a date other than 19 Jan. Daytime maxima ranged from 14 to $21 \mathrm{C}$ for 25,26 , and 27 Jan., followed by lows of $-8 \mathrm{C}$ on 31 Jan. (Fig. 1) and $-11 \mathrm{C}$ on $1 \mathrm{Feb}$. Therefore, bud injury could have occurred during this period due to loss of hardiness from the unusual high temperatures followed by minima almost as low as those experienced on 19 Jan. Wolf and Cook (1992) reported a loss of hardiness of grape buds
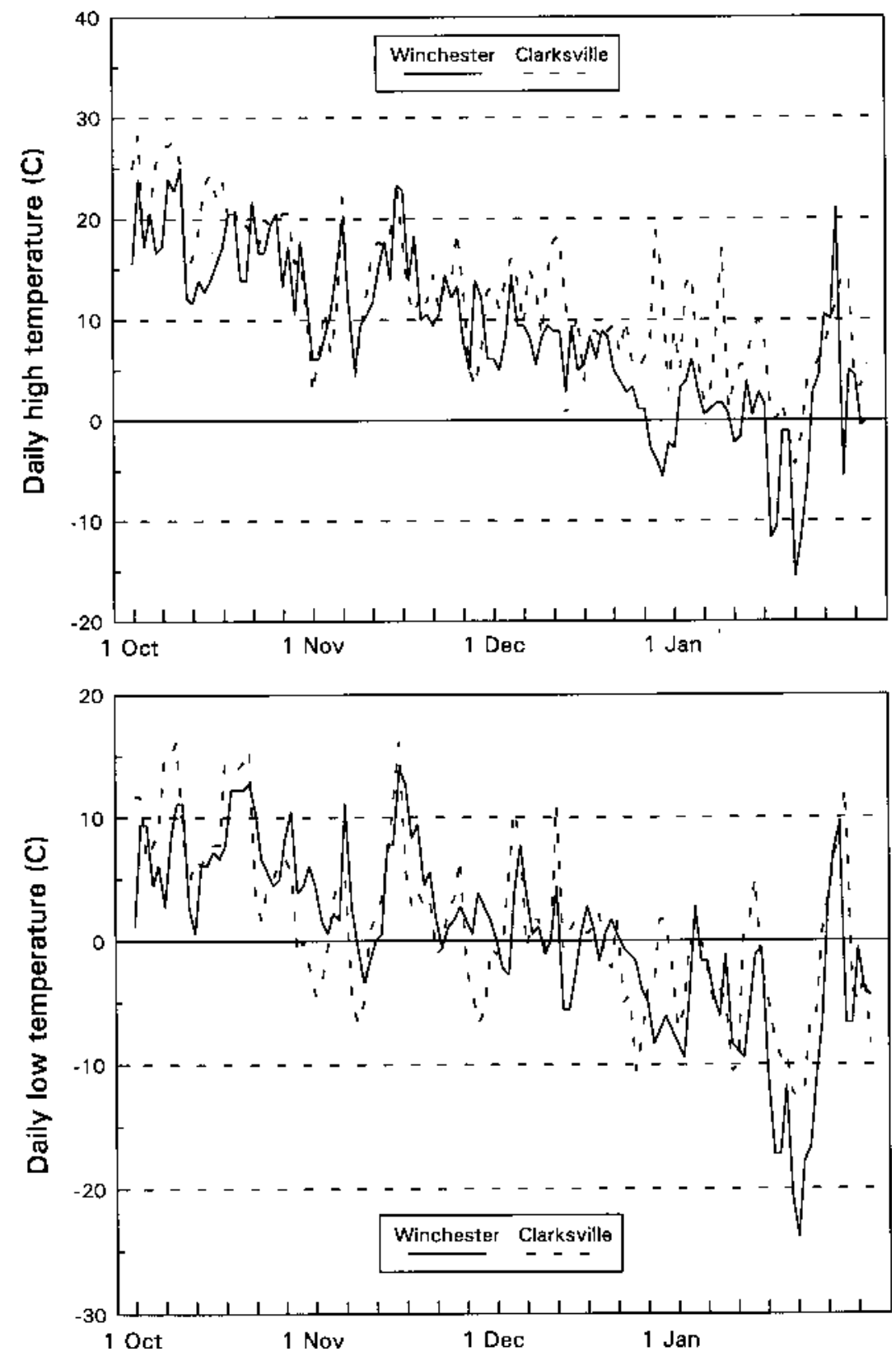

Fig. 1. Daily high (upper) and low (lower) temperatures for Winchester, Va., and Clarksville, Ark., vineyards from 1 Oct. 1993 to 31 Jan. 1994.

when exposed to $23 \mathrm{C}$ during the dormant period and also found that 'Concord' ( $V$. labrusca) deacclimated more rapidly than 'Cabernet Sauvignon' ( $V$. vinifera L.). The total bud injury in our study could have re- sulted from accumulated damage at both of these minimum temperature periods (19 Jan. and 1 Feb.). However, bud kill data were not collected at any date other than 10 Feb. during the dormant season. 
'Mars' buds from vines grown at Winchester had MLTEs that were lower than those from Clarksville 'Mars' vines on all but one date. A low of -24C occurred at the Winchester AREC on 19 Jan. 1994 (Wolf and Cook, 1994) and resulted in $27 \%$ dead $(n=52)$ primary buds with 'Mars'. Daily high and low temperatures (Fig. 1) were typically lower at Winchester than at Clarksville, especially after 1 Dec. The lower Winchester temperatures likely contributed to the lower MLTEs of 'Mars' grown there (Pool et al., 1992). Cultural differences between sites and sample treatment during shipment also may have contributed to differences in apparent hardiness between the two locations. The degree of injury noted is consistent with the TA results of the 7 Jan. test (Table 1). The hardiness (i.e., MLTE temperature) of the Arkansas 'Mars' reported here is similar to that found in an earlier study, in which the midwinter cold hardiness of 'Mars' was superior to that of 'Venus' and 'Saturn' (Bourne et al., 1991).

In conclusion, TA detected exotherms in muscadine grape buds consistent with the number of buds tested. However, cold hardiness of material shipped from Arkansas to Virginia was overestimated based on subsequent field exposure to $-13 \mathrm{C}$ and bud viability assays. Further research is needed to compare TApredicted hardiness with actual field hardiness of muscadine grapes under as carefully controlled and recorded conditions as feasible.

\section{Literature Cited}

Ahmedullah, M. and D.G. Himelrick. 1990. Grape management, p. 383-471. In: G.J. Galletta and D.G. Himelrick (eds.). Small fruit crop management. Prentice Hall, Englewood Cliffs, N.J.

Andrews, P.K, C.R. Sandidge, III, and T.K. Toyama. 1984. Deep supercooling of dormant and deacclimating Vitisbuds. Amer. J.Enol. Viticult. 35:175-177.

Bourne, T.F., J.N. Moore, and M.F. George. 1991. Primary bud hardiness of four genotypes of grapes in Arkansas. J. Amer. Soc. Hort. Sci. 116:835-837.

Clark, J.R. and J.N. Moore. 1990. Winter damage to muscadine grape cultivars, p. 78-80. In: Proc. 111th Annu. Mtg. Ark. State Hort. Soc. Fort Smith, Ark., 14-15 Nov. 1990.

Hamman, R.A., Jr., A.R. Renquist, and H.G. Hughes. 1990. Pruning effects on cold hardiness and water content during deacclimation of Merlot bud and cane tissues. Amer. J. Enol. Viticult. 41:251-260.

Pierquet, P. and C. Stushnoff. 1980. Relationship of low temperature exotherms to cold injury in Vitis riparia Michx. Amer. J. Enol. Viticult. 31:1-6.

Pierquet, P., C. Stushnoff, and M.J. Burke. 1977. Low temperature exotherms in stem and bud tissues of Vitis riparia Michx. J. Amer. Soc. Hort. Sci. 102:54-55.

Poling, E.B., C.M. Mainland, and J.B. Earp. 1989. Muscadine grape production guide for North Carolina. North Cariolina Agr. Ext. Serv. Bul. AG-94.
Pool, R.M., T.K. Wolf, M.J. Welser, and M.C. Goffinet. 1992. Environmental factors affecting dormant bud acclimation of three Vitis cultivars, p. 611-616. Proc. IV Intl. Symp. Physiol. Vine, San Michele All'Adige, Italy, 10-15 May 1992.

Quamme, H.A. 1986. Use of thermal analysis to measure freezing resistance of grape buds. Can. J. Plant Sci. 66:945-952.

Wample, R.L. 1994. A comparison of short- and long-term effects of mid-winter pruning on cold hardiness of Cabernet Sauvignon and Chardonnay buds. Amer. J. Enol. Viticult. 45:388-392.

Wample, R.L., S.E. Spayd, R.G. Evans, and R.G. Stevens. 1993. Nitrogen fertilization of white Reisling grapes in Washington: Nitrogen seasonal effects on bud cold hardiness and carbohydrate reserves. Amer. J. Enol. Viticult. 44:159167.

Wolf, T.K. and M.K. Cook. 1992. Seasonal deacclimation patterns of three grape cultivars at constant, warm temperature. Amer. J. Enol. Viticult. 43:171-179.

Wolf, T.K. and M.K. Cook. 1994. Cold hardiness of dormant buds of grape cultivars: Comparison of thermal analysis and field survival. HortScience 29:1453-1455.

Wolf, T.K. and R.M. Pool. 1986. Microcomputerbased differential thermal analysis of grapevine dormant buds. HortScience 21:1447-1448.

Wolf, T.K. and R.M. Pool. 1987. Factors affecting exotherm detection in the differential thermal analysis of grapevine dormant buds. J. Amer. Soc. Hort. Sci. 112:520-525. 